\title{
CONSUMER BEHAVIOR PREDICTION ANALYSIS BASED ON RATIONALISM AND UNDERSTANDING ABOUT CONSEQUENCES TOWARDS PIRATED DIGITAL PRODUCTS
}

\author{
Palus and Jony Oktavian Haryanto \\ Graduate Program Student, Economics Faculty PelitaHarapan University and Graduate \\ Program Student, Economics Faculty President University \\ Email: jonyharyanto@yahoo.com
}

\begin{abstract}
This research is conducted to examine consumer perception related with rationalization and understanding of risk consequences and their advantages by predicting desires related with digital product piracy. The motivation to conduct digital piracy is reinforced with understanding the advantages obtained and consumer behavior towards digital product piracy. Various rationalization techniques also support reinforcing their motivation to engage in piracy. Interestingly, that motivation can be hindered with perceptions about the consequences or social norm regulations and moral responsibilities. Analytical results reveal that consumer intention to use pirated digital products can continuously increase, because it is influenced by the understanding of the advantages obtained, the rational techniques used, their attitudes toward piracy, and perceptions in controlling behavior. On another side, moral responsibilities and social norms also play a role in reducing the intensity of using pirated digital products.
\end{abstract}

Keywords: Perceived risk, perceived benefits, rationalization, moral obligations, attitudes, subjective norms, perceived behavioral control, piracy intention.

\section{INTRODUCTION}

More than half of the Internet users worldwide have admitted to using pirated digital products. This was stated from survey results by Business Software Alliance (BSA), which was quoted in the article BSA Global Software Survey 2013, in which Indonesia is ranked $3^{\text {rd }}$ as one of the biggest countries to engage in software piracy in the Asia Pacific region at 84\%, after Bangladesh (87\%) and Pakistan (85\%). Digital piracy is an activity to copy and/or download illegally licensed digital products (Cronanand Al-Rafee, 2008). This digital pirating activity has mushroomed all over Indonesia. This activity has even caused the digital product industries in Indonesia like the music industry, film industry, and software applications to experience great financial losses. This was revealed in a survey conducted by Business Software Alliance(BSA), where the potential loss in Indonesia from software piracy reached USD 1.463billion in 2013 (BSA, 2013).

Actually, the Indonesian government has already made an effort to fight piracy and proclaimed that digital piracy is an illegal action and made a commitment to counter this piracy. This was manifested in Amendment No.19, 2002, regarding Copyrights (Amendment No. 19/2002), and updated with Amendment No. 28, 2014, regarding Copyrights (Amendment No. 28/2014). In spite of that, it seems the level of digital piracy in Indonesia is still very high (IIPA, 2013). The reason why digital piracy spreads all over Indonesia is because consumers are unaware or do not care that digital piracy is an illegal action. 
In addition, a classic reason that is often used is that it is cheaper and consumers are forced to use pirated digital products due to their work demands or other activities like they need school equipment for college. This causes the desire to use pirated digital products to remain so high in Indonesia. Another cause is that it is used as a trial test to see whether a certain digital product will be able to gain profitable sales or not. According to Vida et al. (2012), this is one of the reasons to use the rationalization technique (rationalization). Consumers' behavioral patterns and habits (attitudes) also form certain characteristics, so that it causes consumers to enjoy using pirated digital products compared with licensed products.

In general, consumers use a balanced approach in identifying the positive and negative effects for producers (Bhattacharjee et al., 2006). Likewise, consumers play a role in digital piracy, whether in terms of profit (like price advantages), which form an understanding about advantages (perceived benefits), or losses or risks (like computer virus threats), which is the foundation of understanding about risks (Hennig-Thurau, Henning, and Sattler, 2007).

Theoretical Foundation. Piracy Intention. Piracy intention is an individual's tendency or desire to consume or use pirated digital products in the future (Vida et al., 2012). These pirated digital products can be obtained by downloading or through other means like buying or copying through various media like CDs or hard disks. This behavior is usually influenced by previous experiences or understanding about this behavior. Piracy intention, according to Garbharranand Thatcher (2009), is mostly caused by an individual's lack of moral conviction, so that it results in an antisocial attitude, especially in digital product piracy. According to Tan (2002), consumers' tendency to buy or use pirated digital products rather than legalized copies reveals that several components from moral intensity, moral considerations, and risks felt by individuals are factors that influence their decisions in the buying process.

Perceived Risk. Perceived risk is an understanding about risks that can surface from a downloading activity or using illegal digital products like virus attacks, hacking, among others (Vida et al., 2012). In general, perceived risks can also be thought to be a way of thinking that arises from an uncertain feeling about the negative consequences that may occur (Liao, Lin, and Liu, 2010). This understanding about risk will increase in line with the level of uncertainty towards the negative consequences that may occur. As a consequence, these individuals need to understand various information from different sources to make them aware of the risks that may arise.

Perceived Benefit. Perceived benefit is an understanding or belief that downloading illegal digital products has positive consequences offered as a factor that influences individuals to illegally download or use digital products (Yoon, 2011). Yoon also stated that the benefits one can obtain through digital piracy significantly influence one's tendency to use pirated digital products. Even downloading digital music products illegally may provide positive consequences for the user, like through convenience and saving time or money.

Rationalization. Rationalization is a technique to counter feeling guilty related to past experiences (Moore and McMullan, 2009). This behavior is also often done to assure oneself from feeling guilty or challenged with one's conscience. Since the neutralization theory was published, many researchers have applied this theory to research various 
criminal activities done by individuals. Moore and McMullan (2009) concluded that in order for the neutralization technique and rationalization to be applied, first an individual must believe that something is wrong with their behavior, so that they need a justification. Whenever someone does not have a guilty feeling to be neutralized, it can be concluded that there is no need for the neutralization technique.

Moral Obligation. Moral obligation is a part of the deontology theory, which has included in it moral obligation and the justice theory. Moral obligation and the justice concept are often used as ethical factors in discussing about digital product piracy (Yoon, 2011). Cronanand Al-Rafee (2008) stated that moral obligation is a part of the theory of planned behavior (TPB) and becomes a factor in influencing piracy intention.

Attitudes. Attitudes are someone's feelings towards whether characteristics are beneficial or not and then turned into behavior (Ajzen, 1991). From the TPB viewpoint, attitudes are the primary factor to predict whether someone will have a desire to receive or use pirated digital products (Yoon, 2011). The relationship between attitudes and someone's intention is to what extent an individual benefits or does not benefit from engaging in a certain behavior. In research conducted by Lin, Hsu, and Chen (2013), they found that attitudes toward intention refer to consumers' feelings to pay for the cost of an online music service. This concept has been widely examined and tested.

Subjective Norms. Subjective norms, according to Yoon (2011), refer to social pressure that is felt to do or not do a certain behavior. This is also influenced by the strength of each normative belief multiplied by an individual's motivation to adhere to a specific norm. Subjective norms are a depiction of internal and external social influence that affect an individual's intention to use a pirated digital product (Lin, Hsu, and Chen, 2013). This was similarly conveyed by Khang et al. (2012), in that subjective norms function as an individual's perception towards others' significant viewpoint, like a peer group, which is trusted as something which should or should not be done related with a certain behavior.

Perceived Behavioral Control. Perceived behavioral control can capture an individual's perception about their capability to act according to past experiences and ability to anticipate problems such as skills, abilities, opportunities, motivation, and dependence in other people (Foltz, Newkirk, and Schwager, 2010). This behavior usually needs skills, opportunities, or resources to be done. Adding perceived behavioral control to TPB also facilitates becoming a model to handle more complex behaviors. Perceived behavioral control only focuses on control perception that is done than the actual control. Perceived behavioral control also influences direct behavior. Individuals may be more involved in behavior that they control and feel able to change their social network security settings.

Hypotheses. Vida et al. (2012) conducted research centered on individual understanding of using pirated digital products and using rationalization towards their behavior. Meanwhile, research done by Khanget al. (2012) focused on intensity in using pirated digital products based on the theory of planned behavior (TPB). Therefore, this research combines both models to become a new model as follows: 


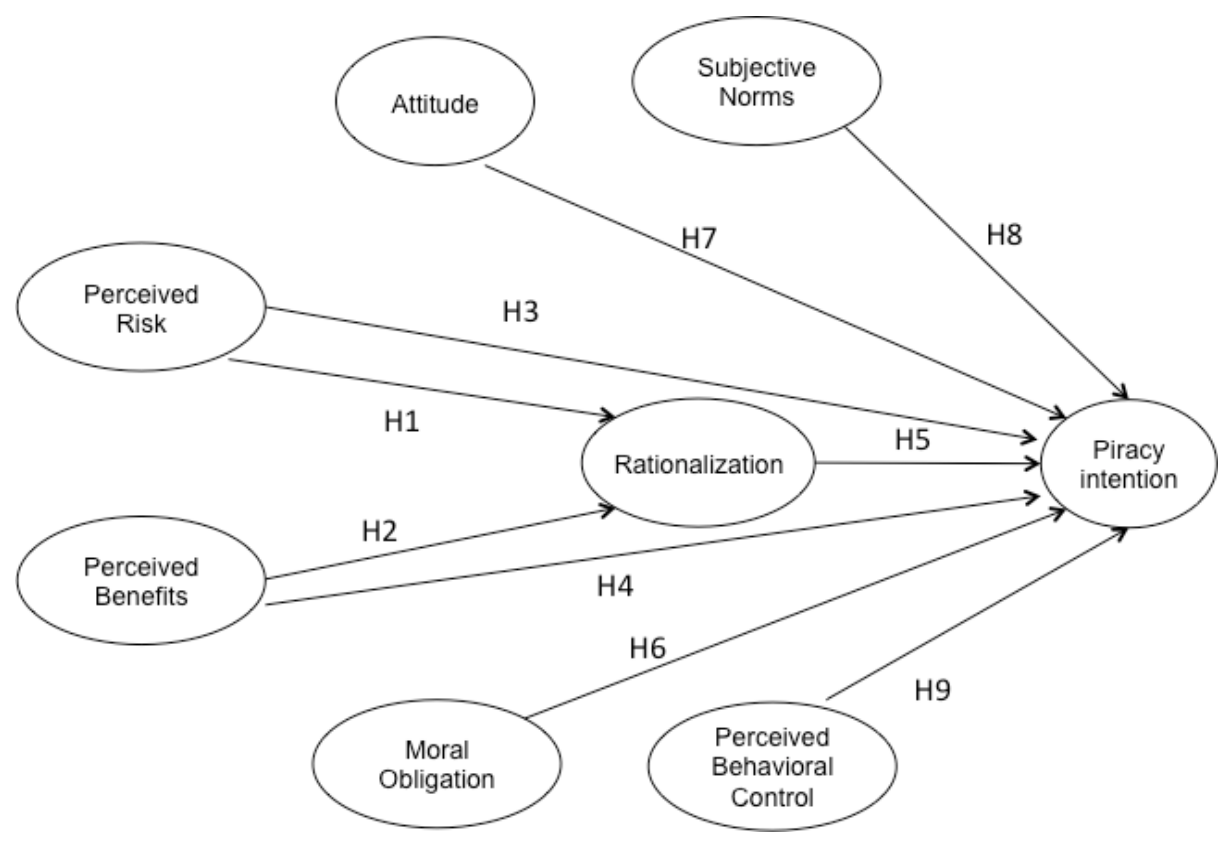

Figure 1. Conceptual Model

Based on the results of this combined model, the following hypotheses can be formulated: H1. Perceived risk has a negative influence towards level of rationalization.

H2. Perceived benefit has a positive influence towards level of rationalization.

H3. Perceived risk has a negative influence towards piracy intention.

H4. Perceived benefit has a positive influence towards piracy intention.

H5. Rationalization has a positive influence towards piracy intention.

H6. Moral obligation has a negative influence towards piracy intention.

H7. Attitude has a positive influence towards piracy intention.

H8. Subjective norms have a negative influence towards piracy intention.

H9. Perceived behavioral control has a positive influence towards piracy intention.

\section{RESEARCH METHODS}

Type of Research, Population Description, and Sample. A descriptive quantitative research is used to depict an understanding of the consequences and rationalization towards using pirated digital products. A description of the population used in this research is as follows: (1) Men and women between 18 and 55 years old who live in Jakarta and Surabaya; (2) They have used the Internet within the last year; (3) They have downloaded or used pirated digital products.

The sample retrieving method used in this research is nonprobability sampling with a convenience sampling technique. A total of 200 respondents are chosen for the sample.

Measurement Methods. All of the measurements use the newest questionnaires adapted from Vida et al. (2012), Yoon (2011), Thurau, Henning, and Sattler (2007), Liao, Lin, and Liu (2009), Panasand Ninni (2011), and finally from Garbharranand Thatcher (2009). The questions used are first translated into Indonesian language and then examined by 
conducting a pretest before being used as a research survey. This research uses a Likert scale starting from 1 (strongly disagree) to 5 (strongly agree). The indicators used to measure the 9 variables are: perceived risk ( 5 items), perceived benefit ( 5 items), rationalization (5 items), moral obligation (5 items), attitude (4 items), subjective norms (4 items), perceived behavioral control (5 items), and piracy intention (4 items).

Analysis and Discussion. The questionnaires were distributed online to 200 respondents, who reside in Jakarta and Surabaya. From the respondents who answered, there were 2 respondents who had the biggest outlier data, so that the total was reduced to become 198 respondents. The profile of the respondents was based on their gender with $55 \%$ males and $45 \%$ females. The ages ranged from 18-25 years old (73\%),26-35 years old (24\%), and 36-55 years old (3\%). The profile of the respondents was also based on their educational background with $48 \%$ having an undergraduate degree, $42 \%$ having a high school / vocational high school degree, 7\% having an associate degree, and 3\% having a master's degree. The profile based on occupation revealed 53\% are employees/entrepreneurs, 39\% are high school / university students, and 8\% are unemployed.

Outer Model Analysis Test Results. In measuring the Outer Model, the relationship between indicators and latent variables is seen. This questionnaire is validated by looking at the factor loading value and AVE value. According to Chang, Wang, and Yang (2008), the loading factor needs to be examined from indicators and from the loading factor averages of each indicator for every latent variable.

Convergent Validity can be seen from two parameters: the loading factor value and the AVE value. The loading factor value and AVE value are considered valid whenever they are above $>0.5$. From these results, there are 5 invalid variables, such as the perceived risk variable reveals the AVE value is lower than 0.5 at 0.47 . Likewise, with the perceived benefit variable, it reveals an AVE value of 0.44 . The rationalization variable shows that the AVE value is 0.46 . For the moral obligation variable, it reveals an AVE value of 0.51 , but the MO5 indicator has a loading factor of 0.45 with an AVE value of 0.51 . This is similar with the perceived behavioral control variable for the PC1 indicator, which has a loading factor of 0.47 and an AVE value of 0.58 .

Several indicators were eliminated from the perceived risk variable like PR1 and PR2. Then for the perceived benefit variable, the PB1, PB2, and PB5 indicators were expelled. For the rationalization variable, the R1 and R3 variables were eliminated. Then for the moral obligation variable, the MO5 indicator was expelled. Finally, for the perceived behavioral control variable, the PC1 indicator was eliminated. After all of the indicators were expelled, a reestimation was conducted to see the results of the Outer Model analysis.

Table 1. Outer Model Test Results after Model Modification

\begin{tabular}{ccccc}
\hline \multirow{2}{*}{ Variable } & Indicator & \multicolumn{2}{c}{ Convergent Validity } & \multirow{2}{*}{$\begin{array}{c}\text { Composite } \\
\text { Reliability }\end{array}$} \\
\cline { 3 - 4 } & & Loading Factor & AVE & \\
\hline \multirow{2}{*}{ Perceived Risk } & PR3 & 0.73 & 0.61 & 0.82 \\
& PR4 & 0.78 & & \\
Perceived & PR5 & 0.83 & 0.61 & 0.76 \\
Benefit & PB3 & 0.84 & 0.72 & \\
\hline
\end{tabular}


Palus and Haryanto: Consumer Behavior Prediction Analysis Based on Rationalism...

\begin{tabular}{|c|c|c|c|c|}
\hline & $\mathrm{R} 2$ & 0.65 & & \\
\hline \multirow[t]{3}{*}{ Rationalization } & R4 & 0.81 & \multirow[t]{2}{*}{0.52} & \multirow[t]{2}{*}{0.76} \\
\hline & R5 & 0.70 & & \\
\hline & MO1 & 0.81 & \multirow{4}{*}{0.57} & \multirow{4}{*}{0.84} \\
\hline Moral & MO2 & 0.82 & & \\
\hline \multirow[t]{3}{*}{ Obligation } & MO3 & 0.69 & & \\
\hline & MO4 & 0.69 & & \\
\hline & AT1 & 0.80 & \multirow{4}{*}{0.54} & \multirow{4}{*}{0.82} \\
\hline \multirow{3}{*}{ Attitude } & AT2 & 0.58 & & \\
\hline & AT3 & 0.80 & & \\
\hline & AT4 & 0.75 & & \\
\hline \multirow{5}{*}{$\begin{array}{c}\text { Subjective } \\
\text { Norms }\end{array}$} & SN1 & 0.85 & \multirow{5}{*}{0.79} & \multirow{5}{*}{0.95} \\
\hline & SN2 & 0.86 & & \\
\hline & SN3 & 0.93 & & \\
\hline & SN4 & 0.94 & & \\
\hline & SN5 & 0.87 & & \\
\hline \multirow{4}{*}{$\begin{array}{c}\text { Perceived } \\
\text { Behavioral } \\
\text { Control }\end{array}$} & PC2 & 0.88 & \multirow{4}{*}{0.66} & \multirow{4}{*}{0.88} \\
\hline & PC3 & 0.92 & & \\
\hline & PC4 & 0.71 & & \\
\hline & PC5 & 0.72 & & \\
\hline \multirow{4}{*}{ Piracy Intention } & PI1 & 0.85 & \multirow{4}{*}{0.59} & \multirow{4}{*}{0.85} \\
\hline & PI2 & 0.78 & & \\
\hline & PI3 & 0.87 & & \\
\hline & PI4 & 0.53 & & \\
\hline
\end{tabular}

Source: 2015 Primary Data

Table 1 shows the loading factor values and AVE values are better than before. The loading factor results are not below 0.50 and AVE values are above $>0.50$, so that the results are valid. Then the composite reliability (CR) values of all the variables are above $>0.70$, so that the results are reliable.

Goodness of Fit Model Test Results. Research that uses an SEM model needs to be tested with a goodness-of-fit to confirm that the model used is appropriate (fit). According to Hooper, Coughlan, and Mullen (2008), in keeping in mind the level of complexity from SEM, oftentimes the models used produce bad results. In an SEM model analysis, a model modification can be done based on the orientation of the results from the confirmatory factor analysis test. From testing the Outer Model, several indicators are found that can be eliminated: PR1, PR2, PB1, PB2, PB5, R1, R3, MO5, and PC1. Then 2 respondents who have the biggest outlier data are eliminated. Based on the theory, model modification can be done to acquire more appropriate (fit) model results. The following table shows the model tested by using goodness of fit:

A CMIN/DF value of 1.830 reveals a good structural equation model. An RMSEA measuring index of 0.065 conveys that RMSEA is in an acceptable range. This is similar with a CFI of 0.916, which is also in an acceptable range. The Chi-Square is 737.452, while the probability is 0.00. Meanwhile, GFI and RMR are in a marginal range. Based on the test results, it reveals that the model is accepted or valid to continue. It is considered acceptable whenever at least one index of the validity test model is fulfilled (Hair et al., 2009). 
Table 2. Goodness of Fit Test Results

\begin{tabular}{lllll}
\hline No. & Index & Critical Value & Results & Model Evaluation \\
\hline 3 & CMIN/DF & $<2.00$ & 1.830 & Good \\
4 & CFI & $\geq 0.90$ & 0.916 & Good \\
5 & RMSEA & $\leq 0.08$ & 0.065 & Good \\
6 & TLI & $\geq 0.90$ & 0.903 & Good \\
7 & GFI & $\geq 0.90$ & 0.810 & Marginal \\
8 & RMR & $\leq 0.08$ & 0.095 & Marginal \\
\hline
\end{tabular}

Source: 2015 Primary Data

Hypothesis Test Results. After the estimated criteria of the goodness of fit model can be accepted, then the next stage is to analyze the structural relationship between models or hypothesis tests. The relationships between variables in a hypothesis are indicated by regression weight values (Dachlan, 2014). To conduct a further analysis of every variable examined, the following table can be seen:

Table 3. Hypothesis Test Results

\begin{tabular}{|c|c|c|c|c|}
\hline Hypothesis & Hypothesis & t-value & Significance & Results \\
\hline H1 & $\begin{array}{l}\text { Perceived Risk ---> } \\
\text { Rationalization }\end{array}$ & -0.254 & Not significant & Rejected \\
\hline $\mathrm{H} 2$ & $\begin{array}{l}\text { Perceived Benefit ---> } \\
\text { Rationalization }\end{array}$ & 3.763 & Significant & Accepted \\
\hline H3 & $\begin{array}{c}\text { Perceived Risk ---> Piracy } \\
\text { Intention }\end{array}$ & -1.993 & Significant & Accepted \\
\hline $\mathrm{H} 4$ & $\begin{array}{c}\text { Perceived Benefit ---> Piracy } \\
\text { Intention }\end{array}$ & 2.741 & Significant & Accepted \\
\hline H5 & $\begin{array}{c}\text { Rationalization ---> Piracy } \\
\text { Intention }\end{array}$ & 3.095 & Significant & Accepted \\
\hline H6 & $\begin{array}{c}\text { Moral Obligation ---> Piracy } \\
\text { Intention }\end{array}$ & -2.017 & Significant & Accepted \\
\hline H7 & $\begin{array}{l}\text { Attitude ---> } \\
\text { Piracy Intention }\end{array}$ & 4.762 & Significant & Accepted \\
\hline H8 & $\begin{array}{c}\text { Subjective Norms ---> Piracy } \\
\text { Intention }\end{array}$ & -4.931 & Significant & Accepted \\
\hline H9 & $\begin{array}{c}\text { Perceived Behavioral Control --- } \\
> \\
\text { Piracy Intention }\end{array}$ & 3.502 & Significant & Accepted \\
\hline
\end{tabular}

Source: 2015 Primary Data 
Hypothesis 1, Perceived risk does not have a negative influence towards rationalization. The hypothesis test results convey that this hypothesis is rejected, but the perceived risk has a negative influence on rationalization. The results of the hypothesis tests are the same as previous research conducted by Vida et al. (2012), who stated that perceived risk does not have a significant negative relationship towards rationalization. According to Vida et al. (2012), this is due to perceived risk not being cognitively connected with rationalization. The rationalization technique will surface whenever it is done as a behavior rather than rationalizing understanding about risks that have been done in the past. Therefore, the rationalization technique is not relevant.

Related with the newest research, if seen from age range, the majority of respondents are teenagers ranging in age from 18-25 years old (72\%), which is a developing age range both physically and psychologically. In general, teenagers actively build their own cognitive world, where the information that they receive is not directly accepted in their cognitive scheme. So they will choose information or whatever understanding is needed to be justified by using a rationalization technique. Besides that, teenagers also have a tendency to make sensational changes and neglect risky things in doing a rationalization process towards their actions (Sheehan and Tsao, 2009).

Hypothesis 2, Perceived benefit has a positive influence towards rationalization. The hypothesis test results reveal that perceived benefit has a significant positive influence on rationalization, so that this hypothesis is accepted. According to Vida et al. (2012), perceived benefit has a positive consequence and big influence in forming consumers' rationalization. This gives consumers a reason to take advantage of piracy and is a positive reason towards their actions in the past.

If seen from the side of education and age, the majority of respondents in the research are 18-25 years old (72\%), and the majority of them have an undergraduate education level (48\%) and high school / equivalent level (42\%), which means that the majority of them are university students or recent graduates. In general, high school students or the equivalent and university students have much experience in operating computers. They have enough up-to-date knowledge about computers. In addition, the frequency and time that they use computers is also high. According to Rahim, Rahman, and Seyal (2000), high school students and the equivalent as well as university students need more digital products, especially software to do their tasks, while not all the software they need is available at campus. The majority of software is rather expensive.

Hypothesis 3, Perceived risk has a negative influence towards piracy intention. The hypothesis test results reveal that perceived risk has a significant negative influence towards piracy intention, so that this hypothesis is accepted. In previous research by Vida et al. (2012), it seems perceived risk was also found to have a negative influence on piracy intention. In general, consumers have risk considerations in using pirated digital products if seen from the risk value that surfaces when there is damage, low quality, and social risk like legal ramifications and seizures (Nursaidah, 2013). Several other risk possibilities are product quality is not as good as the original product, there is no guarantee from the seller, there is no financial profit, it is not as comfortable and safe as the original product, choosing a pirated product will influence how other people view the user, and consumers will waste time and feel uncomfortable. In addition, it was found by ANTARA news 
(2010) that 53\% of respondents have experienced data loss and identity theft as a result of the worst aspect of pirated software usage.

Hypothesis 4, Perceived benefit has a positive influence towards piracy intention. The hypothesis test results reveal that perceived benefit has a significant positive influence on piracy intention, so that this hypothesis is accepted. According to Yoon (2011), perceived benefit can become an assurance when the positive consequence that is found from using a pirated digital product becomes a factor that influences one to use pirated digital products in the future. Similarly, Vida et al. (2012) in their research concluded that perceived benefit has a great effect towards intensity in using future pirated digital products. Then consumers make a commitment to use pirated digital products in the future.

For consumers in Indonesia, pirated digital products can easily be found, whether in stores or through the Internet, and they also feel the advantages of this usage. Moreover, according to Hidayatand Mizerski (2005), many consumers intentionally buy pirated digital products because they believe the quality is the same as the original or licensed digital products.

Hypothesis 5, Rationalization has a positive influence towards piracy intention. The hypothesis test results reveal that rationalization has a significant positive influence towards piracy intention, so that this hypothesis is accepted. These results support previous research, in which Vida et al. (2012) stated that rationalization has a positive influence towards piracy intention. According to Vida et al. (2012), this can be stated as an effect from past behavior with a desire for a certain behavior in the future. The reason is that when a person uses a rationalization technique, this increases one's level of selfconfidence to engage in piracy again in the future. In neutralization/rationalization teaching, it facilitates individuals to justify their behavior and make it more acceptable (Hinduja, 2007). By using a rationalization technique, it helps an individual to free oneself from conventional behavior such as respecting copyrights and opens the opportunity to engage in future digital product piracy.

Hypothesis 6, Moral obligation has a negative influence towards piracy intention. The hypothesis test results reveal that moral obligation has a significant negative influence on piracy intention, so that this hypothesis is accepted. According to Khang et al. (2012), this is due to a higher value of moral responsibility that is implanted in society. Even Cronan and Al-Rafee (2008) stated that moral obligation is a significant predictor of piracy intention. This is supported with research results done by Yoon (2011), who concluded that moral obligation is a factor that greatly determines piracy intention. This infers that teenagers realize that this is immoral because it is disadvantageous for others. Moreover, in research conducted by Jayanti, Djamaludin, and Latifah (2011), they found that the majority of teenagers do not agree with doing digital product piracy.

Hypothesis 7, Attitude has a positive influence towards piracy intention. The hypothesis test results reveal that attitude has a significant positive influence on piracy intention, so that this hypothesis is accepted. In previous research, it was found that many South Korean university students have an attitude that is able to become a positive influence for piracy intention in the future. Likewise, in research results surmised by Yoon 
(2011), the same results were found where attitude is a predictor to engage in piracy in the future.

If seen from respondents' profiles of whom the majority are young between the ages of 18-25 years old or recent university graduates or current university students, it reveals a positive attitude related with pirated digital product usage, which is an indicator of the tendency to use pirated digital products in the future (Rahim, Rahman, and Seyal, 2000). Besides that, Indonesian youth consumer behavior, according to Jayanti, Djamaludin, and Latifah (2011),has a positive attitude towards pirated digital product usage, and this action can be seen as a good solution.

Hypothesis 8, Subjective norms have a negative influence towards piracy intention. The hypothesis test results reveal that subjective norms have a significant negative influence on piracy intention, so that this hypothesis is accepted. Previous research results conducted by Khang et al. (2012), reveal that subjective norms have a negative influence on piracy intention. This is possible because there are norms in effect that make individuals have negative effects on the desire to do piracy in the future. This is in line with research done by Yoon (2011), who found that subjective norms have a negative influence on piracy intention and are a predictor to find out one's desire to do digital product piracy in the future. Social factors are influenced by the family, membership groups like organizations, and cultural factors that are integrated with one's life norms (Jayanti, Djamaludin, and Latifah, 2011). Therefore, social norms can influence one's decision to utilize pirated digital products.

Hypothesis 9, Perceived behavioral control has a positive influence towards piracy intention. The hypothesis test results reveal that perceived behavioral control has a significant positive influence on piracy intention, so that this hypothesis is accepted. According to Khang et al. (2012), this occurs as a form of understanding to control behavior or habits, so that it can increase the desire to do piracy in the future. This support is consistent with the expectation that users feel they have the ability to behave based on past experiences and anticipated problems, as well as their skills, opportunities, pressure, and dependence on other people (Foltz, Newkirk, and Schwager, 2010). The Internet is a primary source for them to search for and find the pirated digital products that they want like films, music, or applications to fulfill their needs or desires.

\section{CONCLUSION}

Overall, these research results reveal that perceived benefit, rationalization, attitude, and perceived behavioral control are shown to provide a positive influence towards piracy intention. Meanwhile, perceived risk, moral obligation, and subjective norms are also revealed to have a negative influence on piracy intention. Similarly, perceived benefit also has a positive influence on rationalization. Nevertheless, perceived risk does not have a negative influence on rationalization.

Managerial Implications. The managerial implications in this research are related to users and stakeholders of the digital product industry in conducting digital business activities in Indonesia. Based on this research, digital product industry users, especially producers and license holders, must realize that the tendency to engage in piracy (piracy 
intention) can be predicted by looking at to what extent they understand about the risks of piracy (perceived risks) and understand about the advantages of piracy (perceived benefits), the way they use the rationalization technique (rationalization), an awareness of their moral responsibility (moral obligation), their attitudes towards pirated digital products (attitudes), the social/subjective norms effective in their environment (subjective norms), and the level of understanding to engage in behavioral control (perceived behavioral control). Socialization about the effects of digital product piracy and the benefits of using real or licensed digital products need to be done on a wider scale as an effort to reduce the desire to use pirated digital products.

For digital product producers and education practitioners, they need to increase education programs about digital products, so that it increase appreciation towards intellectual property rights, especially to the young generation. Have contests such as online games and develop applications as incubation programs for university students who want to establish their own enterprises. Besides education, digital rights management (DRM) and music/movie stores can be developed, including finding viable solutions to reduce the intensity of using pirated digital products. This can change their attitudes and rationalization to get them to use licensed digital products. Therefore, it is suggested that digital music and film producers apply these solutions to attract Indonesian consumers' interest, in order that they switch from using pirated digital products to licensed digital products.

Advice. Some suggestions are offered for future research to improve the limitations that are listed above: (1) It is better for respondents to be chosen in balance according to age, education level, and residential area. This is necessary when keeping in mind that respondents who have different ages, education levels, and residential areas can have different influences; (2) In order to make the research results more in-depth, it is suggested to conduct differential tests between male and female respondents. This is based on men's and women's different viewpoints in using pirated digital products; (3) This study found indications that motivation, gender, and purchasing power are influencing factors in using pirated digital products. Therefore, it is suggested that future research also delve further into the influence of motivation, gender, and purchasing power to enrich the research results.

\section{REFERENCES}

Ajzen, I. (1991) "The theory of planned behavior”, Organizational behavior and human decision processes, 50 (2): 179-211.

ANTARA News. “Konsumen Indonesia LebihPilih Software Asli”, accessed on 8 November 2015, <http://www.antaranews.com/berita/234201/konsumen-indonesialebih-pilih-software-asli>, 2010.

Bhattacharjee, S., Gopal, R., Lertwachara, K., and Marsden, J.R. (2006) "Whatever happened to payola? An empirical analysis of online music sharing”.Decision Support Systems, 42 (1): 104-20.

BSA."2013 BSA global software survey”, accessed on 15July 2015, $<$ http://globalstudy.bsa.org/2013/downloads/studies/2013GlobalSurvey_ Study_en.pdf>, 2014. 
Chang, H. H., Wang, Y. H., and Yang, W. Y. (2009) "The impact of e-service quality, customer satisfaction and loyalty on e-marketing: Moderating effect of perceived value”.Total Quality Management, 20 (4): 423-443.

Cronan, T. P. and Al-Rafee, S. (2008) "Factors that influence the intention to use pirated software and media”. Journal of Business Ethics, 78 (4): 527-545.

Dachlan, Usman. (2014) Panduanlengkap structural equation modeling tingkatdasar, $1^{\text {st }}$ edition, LenteraIlmu, Jakarta.

Foltz, B., Newkirk, H. E., and Schwager, P. H. (2010) “An Empirical Investigation of Factors that Influence Individual Behavior toward Changing Social Networking Security Settings". Journal of Theoretical and Applied Electronic Commerce Research, 5 (1): 1-16.

Garbharran, A. and Thatcher, A. (2009) "A case for using a social cognitive model to explain intention to pirate software".Journal of eHealth Technology and Application, 7 (2): 87-98.

Hair, J. F., Black, W. C., Babin, B. J., and Anderson, R. E. (2009) Multivariate data analysis, $7^{\text {th }}$ edition, Pearson Prentice Hall, New Jersey.

Hennig-Thurau, T., Henning, V., and Sattler, H. (2007) "Consumer file sharing of motion pictures”, Journal of Marketing, 71 (4): 1-18.

Hidayat, A. and Mizerski, K. (2005) "Pembajakanproduk: Problema, strategidanantisipasistrategi”, JurnalSiasatBisnis, 1 (10): 99-122.

Hinduja, S. (2007) "Neutralization theory and online software piracy: An empirical analysis". Ethics and Information Technology, 9 (3): 187-204.

Hooper, D., Coughlan, J., and Mullen, M. (2008) "Structural equation modelling: Guidelines for determining model fit”. Electronic Journal of Business Research Methods, 6 (1): 53-60.

Jayanti, T. S., Djamaludin, M. D., and Latifah, M. (2013) "Persepsi, pengetahuan, dan perilaku remaja dalam pembelian compact disk bajakan”. Jurnal Ilmu Keluarga \& Konsumen, 4 (2): 190-198.

Khang, H., Ki, E., and Park, I. (2012) "Exploring antecedents of attitude and intention toward Internet piracy among college students in South Korea”. Asian Journal of Business Ethics, 1 (2): 177-194.

Liao, C., Lin, H. N., and Liu, Y. P. (2010) "Predicting the use of pirated software: A contingency model integrating perceived risk with the theory of planned behavior". Journal of Business Ethics, 91 (2): 237-252.

Lin, T. C., Hsu, J. S. C., and Chen, H. C. (2013) "Customer willingness to pay for online music: the role of free mentality”. Journal of Electronic Commerce Research, 14 (4): 315-333.

Moore, R. and McMullan, E. C. (2009) "Neutralizations and rationalizations of digital piracy: A qualitative analysis of university students”.International Journal of Cyber Criminology, 3 (1): 441-451.

Panas, E. E. and Ninni, V. E. (2011) "Ethical Decision Making in Electronic Piracy: An Explanatory Model based on the Diffusion of Innovation Theory and Theory of Planned Behavior”. International Journal of Cyber Criminology, 5 (2): 836-859.

Rahim, M. M., Rahman, M. N. and Seyal, A. H. (2000) "Softlifting intention of students in academia: A normative model”. Malaysian Journal of Computer Science, 13 (1): 48-55. 
Republik Indonesia, Undang-undangNomor 24 Tahun 2014 tentangHak Cipta. Lembaran Negara RI year 2014 No. 266. Jakarta, 2014.

Sheehan, B., Tsao, J., Bruno, E., Crider, D., Cutrone, J., Jones, C., Kim, S., and Serra, A. (2009) "Improving the effectiveness of anti-digital music piracy advertising to college students". Manuscript submitted for review.

Tan, B. (2002) "Understanding consumer ethical decision making with respect to purchase of pirated software”. Journal of Consumer Marketing, 19 (2): 96-111.

Vida, I., Koklic, M. K., Kukar-Kinney M., and Penz, E. (2012) "Predicting consumer digital piracy, the role of rationalization and perceived consequences”, Journal of Research in Interactive Marketing, 6 (4): 298-313.

Yoon, C. (2011) "Theory of planned behavior and ethics theory in digital piracy: An integrated model”. Journal of Business Ethics, 100 (3): 405-417. 